\title{
Relationship of the Structure of Mescaline and Seven Analogs to Toxicity and Behavior in Five Species of Laboratory Animals ${ }^{1}$
}

\author{
Harold F. Hardman, ${ }^{2}$ Coryce O. HaAvik, ${ }^{2}$ and Maurice H. Seevers ${ }^{3}$ \\ Departments of Pharmacology, Medical College of Wisconsin, Milwaukee, Wisconsin 53233 and \\ The University of Michigan, Ann Arbor, Michigan 48104
}

Received September 26, 1972

\begin{abstract}
Relationship of the Structure of Mescaline and Seven Analogs to Toxicity and Behavior in Five Species of Laboratory Animals. Hardman, H. F., Haavik, C. O. And Seevers, M. H. (1973). Toxicol. Appl. Pharmacol. 25, 299-309. The effect of mescaline and of 7 mescaline analogs $(3,4$-dimethoxy- $\beta$-phenylethylamine; 3,4 -methylenedioxy- $\beta$-phenylethylamine; 3,4-methylenedioxy- $\alpha$-methyl- $\beta$-phenylethylamine; 3,4 -methylenedioxy$\alpha$-ethyl- $\beta$-phenylethylamine; 3,4 -dimethoxy- $\alpha$-methyl- $\beta$-phenylethylamine; 3,4,5-trimethoxy- $\alpha$-methyl- $\beta$-phenylethylamine; and 3,4-methylenedioxy- $N, \alpha$-dimethyl- $\beta$-phenylethylamine) has been studied in the mouse, rat and guinea pig following ip administration and in the mongrel dog and rhesus monkey following iv administration. The LD50 value for each agent has been determined in each species. For 7 of the 8 drugs tested the LD50 value is significantly lower in the rat than in the mouse or guinea pig. A comparison of the observable signs of drug action in the dog and monkey shows the dog to be the preferred species for evaluating the effects of these agents. The relevant literature regarding the actions of the drugs has been reviewed. Modifications in the mescaline structure which are represented by the 7 analogs and which alter pharmacologic activity include: decreased potency following removal of the 5-methoxy group or $\mathrm{N}$-demethylation, and increased potency following alpha substitution on the side chain or introduction of the 3,4-methylenedioxy group.
\end{abstract}

Mescaline was one of the first drugs recognized as having hallucinogenic properties. Although the effects of mescaline in man have been described by many investigators (Stockings, 1940; Hock, 1951), the mechanisms by which mescaline alters central nervous system function are not yet clear. It has been suggested that the psychotomimetic action may arise owing to competition for adrenergic receptors (Ratcliffe, 1971; Speck, 1957), or cholinergic receptors (Clemente and Lynch, 1968), and that psychotomimetic action may result from metabolism in vivo to form an active material (Block et al., 1952).

\footnotetext{
${ }^{1}$ The investigations reported here were performed at the University of Michigan and supported by Army Chemical Center Contract DA-18-108-CML-5663 during the period 1953-54. The reports were declassified in October 1969.

2 Present address: Department of Pharmacology, The Medical College of Wisconsin, Milwaukee, Wisconsin 53233

3 Present address: Department of Pharmacology, The University of Michigan, Ann Arbor, Michigan 48104.
} 
It is possible that some of the difficulties in comparing effects on the human central nervous system with data from experimental animals may be explained on the basis of the choice of laboratory animal model for study. In the investigation reported here, the toxicity of mescaline has been compared in 5 animal species in an effort to identify differences in species sensitivity which may be utilized for further experimental studies. In addition, toxicity data obtained from 7 mescaline analogs permit conclusions regarding structural requirements for the toxicity of agents of this type in the 5 species employed.

\section{METHODS}

Drugs employed in this study were synthesized and supplied by the Army Chemical Center, Edgewood Arsenal. The structural formulas of mescaline (I) and of 7 analogs are shown in Fig. 1.

FIG. 1. Structural formulas of mescaline and seven analogs.<smiles>[R]c1ccccc1</smiles>

\begin{tabular}{|c|c|c|c|c|c|c|}
\hline No. & MW & 5 & 4 & 3 & $\mathrm{R}$ & Name \\
\hline I & 247.4 & $\mathrm{OCH}_{3}$ & $\mathrm{OCH}_{3}$ & $\mathrm{OCH}_{3}$ & $\mathrm{CH}_{2}-\mathrm{CH}_{2}-\mathrm{NH}_{2} \quad 3$, & $\begin{array}{l}\text { 3,4,5-Trimethoxy- } \beta \text {-phenylethyl- } \\
\text { amine } \mathrm{HCl} \text { (mescaline } \mathrm{HCl} \text { ) }\end{array}$ \\
\hline II & 214.4 & $\mathrm{H}$ & $\mathrm{OCH}_{3}$ & $\mathrm{OCH}_{3}$ & $\mathrm{CH}_{2}-\mathrm{CH}_{2}-\mathrm{NH}_{2} 3$, & $\begin{array}{l}\text { 3,4-Dimethoxy- } \beta \text {-phenylethyl- } \\
\text { amine } \mathrm{HCl}\end{array}$ \\
\hline III & 200.0 & $\mathrm{H}$ & $\mathrm{O}-\mathrm{Cl}$ & $\mathrm{H}_{2}-\mathrm{O}$ & $\mathrm{CH}_{2}-\mathrm{CH}_{2}-\mathrm{NH}_{2} 3$, & $\begin{array}{l}\text { 3,4-Methylenedioxy- } \beta \text {-phenyl- } \\
\text { ethylamine } \mathrm{HCl}\end{array}$ \\
\hline IV & 215.5 & $\mathrm{H}$ & $\mathrm{O}-\mathrm{Cl}$ & $\mathrm{H}_{2}-\mathrm{O}$ & $\begin{array}{c}\mathrm{CH}_{2}-\underset{\mid}{\mathrm{CH}}-\mathrm{NH}_{2} \quad 3, \\
\mathrm{CH}_{3}\end{array}$ & $\begin{array}{l}\text { 3,4-Methylenedioxy- } \alpha \text {-methyl- } \beta \text { - } \\
\text { phenylethylamine } \mathrm{HCl}\end{array}$ \\
\hline V & 229.0 & $\mathrm{H}$ & $\mathrm{O}-\mathrm{Cl}$ & $\mathrm{H}_{2}-\mathrm{O}$ & $\begin{array}{c}\mathrm{CH}_{2}-\underset{\mathrm{CH}}{\mathrm{C}}-\mathrm{NH}_{2} \quad 3, \\
\mathrm{CH}_{2} \\
\mathrm{CH}_{3}\end{array}$ & $\begin{array}{l}\text { 3,4-Methylenedioxy- } \alpha \text {-ethyl- } \beta \text { - } \\
\text { phenylethylamine } \mathrm{HCl}\end{array}$ \\
\hline VI & 231.0 & $\mathrm{H}$ & $\mathrm{OCH}_{3}$ & $\mathrm{OCH}_{3}$ & $\underset{\mathrm{CH}_{3}}{\mathrm{CH}_{2}-\underset{\mathrm{CH}}{\mathrm{CH}}-\mathrm{NH}_{2} \quad 3,}$ & $\begin{array}{l}\text { 3,4-Dimethoxy- } \alpha \text {-methyl- } \beta \text { - } \\
\text { phenylethylamine } \mathrm{HCl}\end{array}$ \\
\hline VII & 261.4 & $\mathrm{OCH}_{3}$ & $\mathrm{OCH}_{3}$ & $\mathrm{OCH}_{3}$ & $\underset{\mathrm{CH}_{2}-\underset{3}{\mathrm{CH}}-\mathrm{NH}_{2}}{ }$ & $\begin{array}{l}\text { 3,4,5-Trimethoxy- } \alpha \text {-methyl- } \beta \text { - } \\
\text { phenylethylamine } \mathrm{HCl}\end{array}$ \\
\hline VIII & 229.4 & $\mathrm{H}$ & $\mathrm{O}-\mathrm{Cl}$ & $\mathrm{H}_{2}-\mathrm{O}$ & $\begin{array}{c}\mathrm{CH}_{2}-\underset{\mid}{\mathrm{CH}}-\mathrm{NH}-\mathrm{CH} \\
\mathrm{CH}_{3}\end{array}$ & 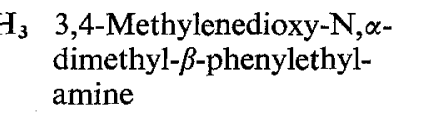 \\
\hline
\end{tabular}

Male and female animals from the following five species were used: SwissWebster mice, Upjohn (Sprague Dawley) rats, guinea pigs, mongrel dogs and Macaca Mulatta monkeys. Drugs were administered ip (mice, rats, guinea pigs) or iv (dogs, monkeys) as a single injection of the hydrochloride salt dissolved in saline 
TABLE 1

Toxicity of Mescaline and Analogs in Five Mammalian Species

\begin{tabular}{|c|c|c|c|c|c|c|c|}
\hline \multirow{2}{*}{$\begin{array}{c}\begin{array}{c}\text { Compound } \\
\text { No. }\end{array} \\
\text { I }\end{array}$} & \multirow{2}{*}{$\begin{array}{l}\text { Species } \\
\text { Mouse }\end{array}$} & \multirow{2}{*}{$\begin{array}{c}\begin{array}{c}\text { Route } \\
\text { of } \\
\text { adminis- } \\
\text { tration }\end{array} \\
\text { ip }\end{array}$} & \multirow{2}{*}{$\frac{N}{40}$} & \multirow{2}{*}{$\begin{array}{c}\mathrm{LD} 50(\mathrm{mg} / \mathrm{kg}) \\
\begin{array}{c}\text { and } 95 \% \\
\text { confidence } \\
\text { limits }\end{array} \\
212(202-222)\end{array}$} & \multicolumn{2}{|c|}{$\begin{array}{l}\mathrm{LD} 50(\mathrm{mmol} / \mathrm{kg} \text { of } \\
\text { base) and } 95 \% \\
\text { confidence limits }\end{array}$} & \multirow{2}{*}{$\begin{array}{c}\begin{array}{c}\text { Molar } \\
\text { toxicity } \\
\text { ratio }\end{array} \\
1.0\end{array}$} \\
\hline & & & & & $0.86^{a}$ & $(0.82-0.90)$ & \\
\hline & Rat & ip & 28 & $132(108-161)$ & 0.53 & $(0.44-0.65)$ & 1.0 \\
\hline & Guinea pig & ip & 32 & $328(289-373)$ & $1.33^{a}$ & $(1.17-1.51)$ & 1.0 \\
\hline & $\operatorname{Dog}$ & iv & 16 & $54 \quad(46-64)$ & 0.22 & $(0.18-0.26)$ & 1.0 \\
\hline & Monkey & iv & 17 & $130(105-161)$ & $0.53^{b}$ & $(0.42-0.65)$ & 1.0 \\
\hline \multirow[t]{5}{*}{ II } & Mouse & ip & 49 & $363(341-386)$ & $1.69^{a}$ & $(1.59-1.80)$ & 0.51 \\
\hline & Rat & $\mathrm{ip}$ & 32 & $146(131-162)$ & 0.68 & $(0.61-0.76)$ & 0.78 \\
\hline & Guinea pig & ip & 20 & $375(351-400)$ & $1.75^{a}$ & $(1.64-1.86)$ & 0.76 \\
\hline & Dog & iv & 16 & $122(109-136)$ & 0.57 & $(0.51-0.63)$ & 0.39 \\
\hline & Monkey & iv & 9 & $220(173-280)$ & $0.98^{b}$ & $(0.81-1.30)$ & 0.54 \\
\hline \multirow[t]{5}{*}{ III } & Mouse & ip & 30 & $176(163-190)$ & $0.88^{a}$ & $(0.82-0.95)$ & 0.98 \\
\hline & Rat & ip & 24 & $55 \quad(42-72)$ & 0.28 & $(0.21-0.36)$ & 1.89 \\
\hline & Guinea pig & ip & 20 & $245(227-265)$ & $1.23^{a}$ & $(1.14-1.32)$ & 1.08 \\
\hline & Dog & iv & 16 & $28 \quad(25-32)$ & 0.14 & $(0.12-0.16)$ & 1.57 \\
\hline & Monkey & iv & 16 & $45 \quad(40-51)$ & $0.22^{b}$ & $(0.20-0.26)$ & 2.41 \\
\hline \multirow[t]{5}{*}{ IV } & Mouse & ip & 92 & $68 \quad(50-92)$ & $0.32^{a}$ & $(0.23-0.43)$ & 2.68 \\
\hline & Rat & ip & 24 & $27 \quad(19-40)$ & 0.13 & $(0.09-0.19)$ & 4.07 \\
\hline & Guinea pig & ip & 60 & $28 \quad(23-45)$ & 0.13 & $(0.07-0.21)$ & 10.02 \\
\hline & $\operatorname{Dog}$ & iv & 17 & $7 \quad(5-10)$ & 0.03 & $(0.02-0.05)$ & 7.34 \\
\hline & Monkey & iv & 18 & $6 \quad(5-9)$ & 0.03 & $(0.02-0.04)$ & 17.65 \\
\hline \multirow[t]{5}{*}{ V } & Mouse & ip & 50 & $82 \quad(74-91)$ & 0.36 & $(0.32-0.40)$ & 2.39 \\
\hline & Rat & ip & 32 & $95(82-108)$ & 0.41 & $(0.37-0.47)$ & 1.29 \\
\hline & Guinea pig & ip & 20 & $88(65-119)$ & 0.38 & $(0.28-0.52)$ & 3.50 \\
\hline & $\operatorname{Dog}$ & iv & 16 & $16(10-26)$ & 0.07 & $(0.04-0.11)$ & 3.14 \\
\hline & Monkey & iv & 16 & $20 \quad(12-33)$ & 0.09 & $(0.05-0.14)$ & 5.89 \\
\hline \multirow[t]{5}{*}{ VI } & Mouse & ip & 40 & $168(157-180)$ & $0.73^{a}$ & $(0.68-0.78)$ & 1.18 \\
\hline & Rat & ip & 32 & $48 \quad(41-57)$ & 0.21 & $(0.18-0.25)$ & 2.52 \\
\hline & Guinea pig & ip & 20 & $195(165-230)$ & $0.84^{a}$ & $(0.72-1.00)$ & 1.58 \\
\hline & Dog & iv & 16 & $59(52-67)$ & 0.26 & $(0.22-0.29)$ & 0.85 \\
\hline & Monkey & iv & 14 & $53 \quad(46-61)$ & 0.23 & $(0.19-0.26)$ & 2.30 \\
\hline \multirow[t]{5}{*}{ VII } & Mouse & ip & 40 & $240(222-259)$ & $0.92^{a}$ & $(0.85-0.99)$ & 0.93 \\
\hline & Rat & ip & 32 & $149(142-156)$ & 0.57 & $(0.54-0.60)$ & 0.93 \\
\hline & Guinea pig & ip & 20 & $172(159-186)$ & $0.65^{a}$ & $(0.61-0.71)$ & 2.04 \\
\hline & Dog & iv & 16 & $23 \quad(18-29)$ & 0.09 & $(0.07-0.11)$ & 2.45 \\
\hline & Monkey & iv & 15 & $31 \quad(25-38)$ & 0.12 & $(0.10-0.15)$ & 4.42 \\
\hline \multirow[t]{5}{*}{ VIII } & Mouse & ip & 50 & $97(89-106)$ & $0.42^{a}$ & $(0.39-0.46)$ & 2.04 \\
\hline & Rat & ip & 32 & $49 \quad(46-52)$ & 0.21 & $(0.20-0.23)$ & 2.52 \\
\hline & Guinea pig & ip & 16 & $98(88-111)$ & $0.43^{a}$ & $(0.38-0.48)$ & 3.09 \\
\hline & Dog & iv & 16 & $14 \quad(8-23)$ & 0.06 & $(0.03-0.10)$ & 3.67 \\
\hline & Monkey & iv & 26 & $22 \quad(17-28)$ & 0.09 & $(0.07-0.12)$ & 5.89 \\
\hline
\end{tabular}

${ }^{a}$ Significantly different $(p<0.05)$ from the value obtained in the rat.

${ }^{b}$ Significantly different $(p<0.05)$ from the value obtained in the dog. 
LD50 values were calculated by the method of Litchfield and Wilcoxon (1949) on the basis of mortality within $24 \mathrm{hr}$ after drug administration. The LD50 values are expressed in the conventional format of $\mathrm{mg} / \mathrm{kg}$ for the hydrochloride salt and as $\mathrm{mmol} / \mathrm{kg}$. The molar toxicity ratio (the LD50 in $\mathrm{mmol} / \mathrm{kg}$ of mescaline $/ \mathrm{LD} 50$ in $\mathrm{mmol} / \mathrm{kg}$ of the analog) has been employed as a measure of relative potency and mescaline was assigned the value of 1.0 . Significant differences were determined with $95 \%$ confidence limits by the Range Overlap test.

Gross observation of the physical and behavioral responses to the drugs were made by trained observers.

\section{Toxicity}

\section{RESULTS}

The lethality of mescaline and of 7 analogs has been determined following ip administration to the mouse, rat and guinea pig and following iv administration to the dog and monkey (Table 1). To aid drug toxicity comparisons, LD50 values are expressed both as $\mathrm{mg} / \mathrm{kg}$ and as $\mathrm{mmol} / \mathrm{kg}$. The LD50 values $(\mathrm{mg} / \mathrm{kg}$ ) obtained following ip administration show distinct differences in species sensitivity to the 8 drugs; the LD50 value is lowest in the rat for all compounds tested with the exception of compounds IV and V. When the data are expressed on a molar basis, the LD50 value in the rat is significantly lower than

TABLE 2

Observed Effects of Mescaline and ANaolgs in the Unanesthetized Dog and Monkey ${ }^{a}$

\begin{tabular}{|c|c|c|c|c|c|c|c|c|}
\hline \multirow[b]{2}{*}{ Observations } & \multicolumn{8}{|c|}{ Compound No. } \\
\hline & $\mathbf{I}$ & II & III & IV & $\mathrm{V}$ & VI & VII & VIII \\
\hline \multicolumn{9}{|l|}{ Motor activity } \\
\hline Ataxia & $\mathrm{D}, \mathrm{M}$ & $\mathrm{D}, \mathrm{M}$ & D & $\mathrm{D}$ & $\mathrm{M}$ & $\mathbf{M}$ & D & $\mathrm{D}, \mathrm{M}$ \\
\hline Convulsions (clonic) & $\mathrm{D}, \mathrm{M}$ & $\mathrm{D}$ & D & $\mathrm{D}, \mathrm{M}$ & $\mathbf{M}$ & & $\mathrm{D}, \mathrm{M}$ & $\mathrm{D}$ \\
\hline Convulsions (tonic) & $\mathrm{D}, \mathrm{M}$ & $\mathrm{D}$ & $\mathrm{D}, \mathrm{M}$ & $\mathrm{D}, \mathrm{M}$ & $\mathrm{D}, \mathrm{M}$ & $\mathrm{D}, \mathrm{M}$ & $\mathrm{D}, \mathrm{M}$ & $\mathrm{D}, \mathrm{M}$ \\
\hline Muscular rigidity & $\mathrm{D}, \mathrm{M}$ & $\overline{\mathrm{D}}, \mathrm{M}$ & $\mathrm{D}, \mathrm{M}$ & $\mathrm{D}, \mathrm{M}$ & $\vec{D}$ & $\mathbf{M}$ & $\mathbf{M}$ & $\mathrm{D}, \mathrm{M}$ \\
\hline Muscle tremors & $\mathrm{D}, \mathrm{M}$ & $\mathrm{D}$ & $\mathrm{D}, \mathrm{M}$ & $\mathrm{D}, \mathrm{M}$ & $\mathrm{D}, \mathrm{M}$ & $\mathrm{D}, \mathrm{M}$ & $\mathrm{D}, \mathrm{M}$ & $\mathrm{D}, \mathrm{M}$ \\
\hline \multicolumn{9}{|l|}{ Autonomic activity } \\
\hline Mydriasis & $\mathrm{D}, \mathrm{M}$ & $\mathrm{D}, \mathrm{M}$ & $\mathrm{D}, \mathrm{M}$ & $\mathrm{D}, \mathrm{M}$ & $\mathrm{D}, \mathrm{M}$ & $\mathrm{D}, \mathrm{M}$ & $\mathrm{D}, \mathrm{M}$ & $\mathrm{D}, \mathrm{M}$ \\
\hline Piloerection & $\mathbf{M}$ & $\mathbf{M}$ & M & $\mathrm{D}, \mathrm{M}$ & & $\mathrm{D}, \mathrm{M}$ & $\mathbf{M}$ & $\mathrm{D}$ \\
\hline Salivation & $\mathrm{D}, \mathrm{M}$ & $\mathrm{D}, \mathrm{M}$ & $\mathrm{D}$ & $\mathrm{D}, \mathrm{M}$ & $\mathrm{D}$ & $\mathrm{D}$ & $\mathrm{D}, \mathrm{M}$ & $\mathbf{D}, \mathbf{M}$ \\
\hline Vascular flushing & $\mathrm{D}, \mathrm{M}$ & $\mathrm{D}, \mathrm{M}$ & & & & & & \\
\hline \multicolumn{9}{|l|}{ CNS activity } \\
\hline Emesis & $\mathrm{D}$ & D & & D & D & $\mathrm{D}, \mathrm{M}$ & $\mathrm{D}, \mathrm{M}$ & $\mathrm{D}$ \\
\hline Apprehension or fright & $\mathrm{D}, \mathbf{M}$ & D & $\mathrm{D}$ & $\mathrm{D}, \mathrm{M}$ & $\mathrm{D}, \mathrm{M}$ & $\mathrm{D}, \mathrm{M}$ & $\mathrm{D}, \mathrm{M}$ & $\mathrm{D}, \mathbf{M}$ \\
\hline Bizarre body attitudes & & $\mathrm{D}$ & & $\mathrm{D}$ & & & D & $\mathrm{D}$ \\
\hline Hallucinations (apparent) & $\mathrm{D}$ & D & D & $\mathrm{D}, \mathrm{M}$ & D & $\mathrm{D}$ & $\mathrm{D}, \mathrm{M}$ & $\mathrm{D}, \mathrm{M}$ \\
\hline Dyspnea & $\mathrm{D}, \mathrm{M}$ & $\mathrm{D}, \mathrm{M}$ & $\mathrm{D}, \mathrm{M}$ & $\mathrm{D}$ & $\mathbf{M}$ & D & $\mathrm{D}, \mathrm{M}$ & $\mathbf{M}$ \\
\hline Hyperpnea & $\mathrm{D}, \mathbf{M}$ & D & $\mathrm{D}$ & $\mathrm{D}$ & D & $\mathrm{D}$ & $\mathrm{D}, \mathrm{M}$ & $\mathrm{D}, \mathrm{M}$ \\
\hline
\end{tabular}

${ }^{a}$ Compounds were given iv over the following dosage range (mg/kg) to dog (D) and monkey (M): I, D 5-60 $(N=22)$, M 10-200 $(N=17)$; II, D 15-200 $(N=27)$, M 50-300 $(N=9)$; III, D 25-75 $(N=24)$, M 30-90 $(N=20)$; IV, D 0.5-15 $(N=27)$, M 1-20 $(N=21) ; \mathrm{V}$, D 5-100 $(N=17)$, M 20-30 $(N=16)$; VI, D 50-75 $(N=16)$, M 30-60 $(N=14)$; VII, D 15-35 $(N=16)$, M 25-75 $(N=19)$; VIII, D 5-50 $(N=28)$, M $10-75(N=28)$. 
that in the mouse or guinea pig for compounds, I, II, III, VI, VII and VIII. Comparison of the iv toxicity of 8 compounds in the dog and monkey indicates that the LD50 values $(\mathrm{mmol} / \mathrm{kg}$ ) are significantly lower in the dog in the cases of compounds I, II and III.

\section{Behavior}

The presence or absence of 15 signs related to motor, autonomic and central nervous system function was noted. These data, summarized in Table 2, were obtained over a wide range of doses, and represent a qualitative response obtainable with each substance. Note that in relatively few cases was an effect noted in the monkey and not seen in the dog. The superiority of the dog as a species for evaluating these compounds was shown by the fact that specific effects consistently observed with mescaline and its analogs in the dog but not in the monkey include: ataxia, clonic convulsions, salivation, emesis, apprehension or fright and apparent hallucinations.

TABLE 3

Structure Activity Relationships IN THE DOG

$\mathrm{LD} 50(\mathrm{mmol} / \mathrm{kg})$ and

Compound $95 \%$ confidence limits $N \quad p$ value

A. Comparison of compounds having identical side chains, different ring structures

$\begin{array}{rlll}\text { III } & 0.14(0.12-0.16) & 16 & <0.05 \\ \text { I } & 0.22(0.18-0.26) & 16 & \\ \text { IV } & 0.03(0.02-0.05) & 17 & <0.05 \\ \text { VII } & 0.09(0.07-0.11) & 16 & \\ \text { III } & 0.14(0.12-0.16) & 16 & <0.05 \\ \text { II } & 0.57(0.51-0.63) & 16 & \\ \text { IV } & 0.03(0.02-0.05) & 17 & <0.05 \\ \text { VI } & 0.26(0.22-0.29) & 16 & \end{array}$

B. Comparison of compounds that differ only in the substituent at position number 5

$\begin{array}{rlll}\text { II } & 0.57(0.51-0.63) & 16 & <0.05 \\ \text { I } & 0.22(0.18-0.26) & 16 & \\ \text { VI } & 0.26(0.22-0.29) & 16 & <0.05 \\ \text { VII } & 0.09(0.07-0.11) & 16 & \end{array}$

C. Comparison of compounds having the same ring structures, different side chains

\begin{tabular}{rlll} 
IV & $0.03(0.02-0.05)$ & 17 & $<0.05$ \\
V & $0.07(0.04-0.11)$ & 16 & \\
IV & $0.03(0.02-0.05)$ & 17 & $<0.05$ \\
III & $0.14(0.12-0.16)$ & 16 & \\
II & $0.57(0.51-0.63)$ & 16 & $<0.05$ \\
VI & $0.26(0.22-0.29)$ & 16 & \\
I & $0.22(0.18-0.26)$ & 16 & $<0.05$ \\
VII & $0.09(0.07-0.11)$ & 16 & \\
III & $0.14(0.12-0.16)$ & 16 & $<0.05$ \\
V & $0.07(0.14-0.11)$ & 16 & \\
\hline
\end{tabular}


The classical pharmacologic response to iv mescaline in the dog is characterized by an immediate hind limb weakness accompanied by a fluttering motion of the hind leg so that the dog is forced to assume a sitting position. Salivation, gagging, emesis and defecation are frequent sequelae to the initial motor effects. The dog may then appear negativistic and assume bizarre body attitudes with the head and neck arched toward the floor and the front legs spread widely apart. During this period, which may last for several hours, the dog shows minimal reaction to loud noises or noxious stimuli. Subsequently, the dog appears to be weak and sleepy; however, when forcefully aroused he exhibits a pronounced hind limb ataxia. With adequate doses the initial motor effect on the hind limb consisting of overt tremors is followed by tonic and clonic convulsions. The convulsive episodes are preceded and followed by barking, yelping and apparent hallucinations. The dog usually exhibits marked mydriasis and runs wildly about the room bumping into walls and furniture. The dog also appears to be apprehensive, frightened and disoriented; barking or snarling at inanimate objects is noted frequently. The 7 analogs of mescaline produce similar qualitative effects in the dog with adequate doses.

\section{Structure-Activity Relationships}

The toxicity of each analog has been compared to that of mescaline in each of the 5 species. It can be seen that the analogs differ greatly in toxicity, and range from approximately 0.5 (compound II in the mouse) to 17 times (compound IV in the monkey) as potent as mescaline. The data indicate that compound II in general is the least potent agent in this series of substances, and that compound IV is the most potent. The relationships between structure and lethality are shown more clearly in Table 3, which summarizes the influence of structural alterations on the LD50 value in the dog. The data suggest that the presence of the methylenedioxy substituent (Table $3, \mathrm{~A}$ ) and of the methoxy group at position number 5 (Table $3, \mathrm{~A}$ ) results in increased toxicity to the dog.

\section{DISCUSSION}

Mescaline (I) (3,4,5-trimethoxy- $\beta$-phenylethylamine) is the primary hallucinogenic alkaloid of peyote. The pharmacology of mescaline in man and in laboratory animals has been reviewed recently (Kapadia and Fayex, 1970) and consequently will not be discussed in detail here.

Five of the 7 mescaline analogs evaluated in this study have been investigated in other laboratories. Compound II (3,4-dimethoxy- $\beta$-phenylethylamine) was synthesized by Skita and Keil (1932) and recently has been shown to be a naturally occurring alkaloid of peyote (Lundstrom and Agurell, 1968). Its pharmacologic activity in the mouse was examined by Epstein et al. (1932), who found it to be a central nervous system depressant devoid of peripheral sympathomimetic activity. The effects of compound II on the central nervous system include alteration of conditioned and escape behavior (Smythies and Levy, 1960; Smythies and Sykes, 1966; Levis and Caldwell, 1971), excitation of the limbic system and/or inhibition of the neocortex (Bridger and Mandel, 1967) and behavioral changes in the rat following intrastriatal administration (Little et al., 1968; Dill et al., 1969). Urinary excretion of compound II by schizophrenic patients was reported by Friedhoff and van Winkle (1962) and has been confirmed by several laboratories. Gunn et al. (1939) reported a positive inotropic and chronotropic 
response to compound II in the isolated perfused cat heart, but were unable to reproduce these results in the isolated perfused rabbit heart. In view of the discrepancies in the results obtained in these two preparations, the authors suggested that rodents may be less susceptible to certain actions of this substance than are other species.

Compound III (3,4-methylenedioxy- $\beta$-phenylethylamine) was classified by Epstein et al. (1932) as a central nervous system stimulant which produces convulsions in mice. Peripheral sympathomimetic action was observed in cats but not in rodents. Gunn et al. (1939) found this substance to have greater pressor activity in the decerebrate cat than did compound II.

Compound IV (3,4-methylenedioxy- $\alpha$-methyl- $\beta$-phenylethylamine) has been reported by Gunn et al. (1939) to be a more powerful central nervous system stimulant in cats, rabbits and mice than is DL-amphetamine. These investigators also reported that compound VI (3,4-dimethoxy- $\alpha$-methyl- $\beta$-phenylethylamine) produced slight tremors and ataxia without marked stimulant effect in mice.

Hey (1947) synthesized compound VII $(3,4,5$-trimethoxy- $\alpha$-methyl- $\beta$-phenylethylamine) and was impressed by the euphoria that resulted from self-administration. Peretz et al. (1955) administered this substance to dogs by rapid iv infusion and noted an acute catatonic reaction of several hours' duration. Oral administration to man $(0.88-2.0 \mathrm{mg} / \mathrm{kg})$ produced nausea, increased motor activity, giddiness, a decrease in inhibitions, increased communicativeness, lack of coordination, bilateral hyperreflexia of the deep tendons, a slight increase in heart rate and hallucinations.

A variety of additional actions of these mescaline analogs have been reported to occur in vivo (Epstein et al., 1932; Gunn et al., 1939; Loman et al., 1941; Hyde et al., 1949) and in vitro (Epstein et al., 1932; Gunn et al., 1939; Mann and Quastel, 1940; Ota, 1948; Ellis, 1949).

The effects of mescaline on a variety of organ systems, both in vivo and in vitro have been described in several species, but toxicity information has been minimal. A variety of mescaline salts exists; these salts differ in molecular weight and in molar content of mescaline base. Consequently, data obtained with the various salts must be compared on the basis of the millimolar content of mescaline base. Speck (1957) reported the LD50 value of mescaline sulfate in the rat to be $370 \mathrm{mg} / \mathrm{kg}$ when administered ip. This value is equivalent to $1.32 \mathrm{mmol}$ mescaline base $/ \mathrm{kg}$, and differs markedly from the value of $0.53 \mathrm{mmol} / \mathrm{kg}$ obtained with mescaline hydrochloride and reported in Table 1 . Delay et al. (1950) reported the LD50 of mescaline sulfate in the mouse to be 177.5 $\mathrm{mg} / \mathrm{kg}$ when administered iv. This value is equivalent to $0.65 \mathrm{mmol}$ mescaline base $/ \mathrm{kg}$, and is of the same order of magnitude as the value of $0.86 \mathrm{mmol} / \mathrm{kg}$ (Table 1) obtained with mescaline hydrochloride administered ip.

In the present investigation, ip LD50 values for mescaline hydrochloride have been obtained in the rat, mouse and guinea pig and are reported to be 123,220 and 370 $\mathrm{mg} / \mathrm{kg}$, respectively. These studies show a significant difference in the toxicity of mescaline in the rat as compared with the mouse or guinea pig. A comparison of relative lethality shows the rat to be approximately twice as sensitive to the lethal effect of mescaline as is the mouse or the guinea pig.

In view of the widespread acceptance of the concept that the monkey is the species of choice for evaluating agents which are hallucinogenic in man, the effects of mescaline hydrochloride in the dog and monkey also were compared. The toxicity data (Table 1) 
indicate that the dog is the more sensitive species (iv LD50 values are 0.22 and 0.53 $\mathrm{mmol} / \mathrm{kg}$ for the dog and monkey, respectively).

The relationship between chemical structure and pharmacological activity of psychoactive agents is an area of considerable interest. In the present study information is presented regarding the toxicity of 7 mescaline analogs in 5 animal species. A comparison of the LD50 (mmol $/ \mathrm{kg}$ ) values obtained for each analog in the species tested shows that, as is the case with mescaline, the rat is in most cases more sensitive to the toxic effects of the agent than are the mouse and guinea pig. Exceptions to this generalization are seen with compounds IV and V, and cannot as yet be explained.

The behavioral responses of the dog and monkey to mescaline and the 7 derivatives tested, show many similarities. Quantitative and perhaps qualitative differences exist, however, since only 3 of the 8 substances tested produced apparent hallucinations in the monkey whereas all the compounds appeared to be hallucinogenic in the dog (Table 2). Note that hallucinatory behavior was not observed in the monkey with mescaline (1) even though iv doses up to $200 \mathrm{mg} / \mathrm{kg}$ were administered.

It is our impression that the dog is superior to the monkey as an experimental subject for predicting psychotomimetic responses characteristic of the mescaline-type drugs. The dog is also more sensitive than the monkey to other pharmacologic and toxicologic effects of mescaline and its analogs, as is illustrated in Tables 1 and 2. Note that the LD50 values for the compounds are lower in the dog than in the monkey. There may be some advantages to using dogs for screening substances for psychotomimetic activity. Most investigators have more experience in recognizing normal and abnormal behavior in dogs than in monkeys. The monkey frequently exhibits stoic behavior in response to stress and he may successfully conceal his anxiety and altered perceptions.

The effects of mescaline in man have been described by many investigators. Stockings (1940), who was among the first to describe in detail these effects, reported the following signs and symptoms after oral administration of $200-500 \mathrm{mg}$ mescaline: mydriasis, conjunctival injection, flushing, mild tremor and incoordination, impaired pain sensation, augmentation of all deep reflexes, hyperpnea, nausea and vomiting, loss of spatial discrimination and exaggerated or prolonged after images, as well as delusions, hallucinations and various other psychic disturbances. All the objective signs, as well as some of the subjective signs described, are discernible following iv administration of mescaline to the dog. However, the dog may require 2-4 times as much of the substance as man to elicit a comparable response. At high doses all dogs exhibited the above effects, at lower doses the percent of animals showing these effects varied directly with the dose. In the doses used, the effects of mescaline in the dog were sufficiently pronounced as to be apparent to several observers, whereas the effects on the monkey were interpreted only by trained observers. The signs reported here to be produced in the dog by mescaline are qualitatively similar to those reported previously by Cochin et al. (1951). No detailed analysis of the effects of mescaline or analogs has been reported until now in the monkey.

The extensive data contained in this report provide a base for further studies in man. A comparison of the observed effects of mescaline and its analogs reported in Table 2 for the dog and monkey with similar studies in man will provide an answer as to the relative value of the dog and monkey as experimental animals for predicting the CNS effects of mescaline-type substances in man. 
The structure-activity relationship of substituted phenylethylamines has been discussed in detail in several recent reviews (Kapadia and Fayez, 1970; Shulgin, 1970; Brawley and Duffield, 1972). The compounds studied contain one or more of the following types of structural modifications : (1) addition of methoxy groups at various positions on the benzene ring, (2) introduction of the methylenedioxy group at ring positions 3-4, or (3) variations in the length and branching of the side chain. Shulgin et al. (1961) had proposed the "mescaline unit" (ED mescaline/ED analog) as a measure of relative potency of mescaline analogs. In this calculation, the effective dose represents the arithmetic mean of the ED1 and ED100 values for the free base. In the data reported here a similar calculation, based on the ratio of LD50 values, has been carried out and is expressed as the "molar toxicity ratio." On the basis of these and other comparisons, several conclusions appear justified regarding the relationship between structure and potency:

1. Removal of the 5-methoxy group from mescaline results in a less potent agent. Smythies and Levy (1960) found compound II to be one-half as potent as mescaline (I) in the rat rope-climbing assay. This difference in potency has been confirmed in the present study. On the basis of LD50 determinations the potency of compound II has been shown to vary from about 0.4 to 0.08 that of mescaline in the 5 species tested. In addition, a comparison of the toxicity of compound I versus II and compound VII versus VI in the dog (see Table 3, B) shows the drugs containing the 5-methoxy substituent (I and VII) to be significantly more potent than those without it (II and VI).

2. N-methylation of mescaline decreases central nervous system potency. The $\mathrm{N}, \mathrm{N}$-dimethyl analog of mescaline has been found to be less potent than mescaline in man (Luduena, 1936) and in rats (Smythies and Sykes, 1966). The studies reported here, in which the $\mathrm{N}$-monomethyl analog of mescaline was employed, support this conclusion. A comparison of the LD50 values ( $\mathrm{mmol} / \mathrm{kg}$ ) for compounds IV and VIII shows that in each species the N-methyl analog (VIII) is less toxic.

3. Alpha substitution on the side chain may alter activity of the drugs in this series. Peretz et al. (1955) reported the hallucinogenic potency of 3,4,5-trimethoxyamphetamine (VII) in man to be similar to that of mescaline, whereas Shulgin (1964) reported it to be less potent than mescaline and qualitatively different. In the studies reported here the effect of alpha-methyl substitution on potency can be seen by comparing the LD50 (mmol $/ \mathrm{kg}$ ) values of compounds II versus VI and compound I versus VII in each species. The data show compound II to be less potent than the corresponding alpha-methylmescaline (VI) in each species tested (Table 1). Mescaline (I) also is less potent than alpha-methylmescaline (VII) in the guinea pig, dog and monkey (Table 1). When the LD50 values for these drugs are compared in the dog, it can be seen that these differences in potency are significant (Table 3, C). A comparison of the corresponding methylenedioxy analogs (III versus IV) also shows that the alpha-substituted compound is more potent (Table 3, C).

The conclusion appears justified that, in the dog, the presence of a methyl or ethyl substitution in the alpha position of the side chain significantly increases toxicity. This can be seen by comparing the LD50 values for compound IV versus V, compound III versus IV, compound I versus VII, and compound II versus VI, as presented in Table 3, C.

4. Introduction of the 3,4-methylenedioxy group alters potency. Shulgin (1964) 
compared the potency of compound VII to that of the corresponding 3,4-methylenedioxy compound in man, and found that the methylenedioxy group increased potency to about 3 times that of mescaline. This conclusion is supported in part by the data presented in Table 1 and Table 3. A comparison of the phenylisopropylamine compound (VI) and its corresponding methylenedioxy analog (IV) shows the LD50 of compound IV to be lower in all 5 species (Table 1). However, in the phenylethylamine series, compound III is not consistently more potent than II (Table 1). A comparison of the potency of compound II versus III and compound VI versus IV in the dog (Table 3, A) shows a significant increase in potency in both methylenedioxy compounds (III and IV) as compared to the corresponding 3,4-dimethoxy analogs (II and VI).

The data now available relating toxicity and pharmacologic activity to the structure of mescaline and its congeners are still inadequate since they do not permit satisfactory prediction of the pharmacologic actions of these agents in man. Such prediction is dependent upon the correlation of information regarding the psychotomimetic activity in man with the effects of these and other agents on the biochemical and behavioral patterns of experimental animals. It has been suggested (Snyder and Richelson, 1968) that psychotomimetic potency in man may be predicted on the basis of chemical conformation, but the reliability of this concept alone in predicting the potency of mescaline analogs appears questionable (Brawley and Duffield, 1972). The problem of predicting activity is further complicated by the inconclusive information regarding the metabolism of mescaline and analogs in various species, and by the meager information concerning the biochemical effects produced by these agents in the central nervous system.

\section{ACKNOWLEDGMENT}

The authors wish to acknowledge the assistance given by Drs. Lauren A. Woods and Thelma C. Gould in our preliminary studies and experimental design.

\section{REFERENCES}

Block, W., Block, K. AND Patzid, B. (1952). Zur Physiologie des ${ }^{14} \mathrm{C}$-radioaktiven Mescaline in Tierversuch. III. Mescalineinbau in Leberprotein. Hoppe-Seyler's Z. Physiol. Chem. 291, 119-128.

Brawley, P. AND Duffield, J. C. (1972). The pharmacology of hallucinogens. Pharmacol. Rev. 24, 31-66.

BRIDGeR, W. H. AND MANDEL, I. J. (1967). The effects of dimethoxyphenylethylamine and mescaline on classical conditioning in rats as measured by the potentiated startle response. Life Sci. 6, 775-781.

Clemente, E. AND Lynch, V. D. (1968). In vitro action of mescaline. Possible mode of action. J. Pharm. Sci. 57, 72-78.

Cochin, J., Woods, L. A. ANd Seevers, M. H. (1951). The absorption, distribution and urinary excretion of mescaline in the dog. J. Pharmacol. Exp. Ther. 101, 205-209.

Delay, J., Gerard, R. AND Thullier, J. (1950). Toxicité aiguë du sulfate de mescaline et antidotisme du succinate de sodium. C. R. Soc. Biol. 144, 1963.

Dill, R. E., Little, M. D. And Matthews, J. L. (1969). Motor disturbances induced by intracranial injection of mescaline or 3-methoxymescaline. Fed. Proc., Fed. Amer. Soc. Exp. Biol. 28, 776 (Abstract).

ELLIS, S. (1949). The action of sympathomimetic amines on the isolated heart of the frog. J. Pharmacol. Exp. Ther. 96, 365-371. 
EPSTEIN, D., GunN, J. A. AND ViRden, C. J. (1932). The action of some amines related to adrenaline. J. Physiol. (London) 76, 224-246.

FRIEDHOFF, A. J. AND VAN WINKLE, E. (1962). Isolation and characterization of a compound from the urine of schizophrenics. Nature (London) 194, 897-898.

GunN, J. A., GuRD, M. R. AND SACHS, I. (1939). The action of some amines related to adrenaline: methoxy-phenylisopropylamines. J. Physiol. (London) 95, 485-500.

Hey, P. (1947). Synthesis of a new homolog of mescaline. Quart. J. Pharm. Pharmacol. 22, 129-134.

Hock, P. H. (1951). Experimentally produced psychoses. Amer. J. Psychiat. 107, 607-611.

Hyde, J., Becket, S. AND Gellhorn, E. (1949). Acetylcholine and convulsive activity. $J$. Neurophysiol. 12, 17-27.

Kapadia, G. J. and Fayez, M. B. E. (1970). Peyote constituents: Chemistry biogenesis, and biological effects. J. Pharm. Sci. 59, 1699-1717.

LeVIS, D. J. AND CALDwell, D. F. (1971). The effects of a low dosage of mescaline and 3,4dimethoxyphenylethylamine under two levels of aversive stimulation. Biol. Psychiat. 3, 251-257.

LitTle, M. D., Dill, R. E. AND NickeY, W. M. (1968). Limb tremors produced in rats by intrastriatal injection of mescaline or 3,4-dimethoxyphenylethylamine. Anat. Rec. 160, 385-386.

LITCHFIELD, J. T. JR. AND WILCOXON, F. (1949). A simplified method of evaluating dose-effect experiments. J. Pharmacol. Exp. Ther. 96, 99-113.

Loman, J., MYerson, P. G. AND Myerson, A. (1941). Experimental pharmacology of postencephalitic Parkinson's disease. Trans. Amer. Neurol. Ass. 67, 201-203.

Luduena, F. P. (1936). Pharmacologie de la trichocéréine, alkaloids du trichocereus terscheki (Parm.) Britton et Rose. C. R. Soc. Biol. 121, 368-369.

LUNDSTROM, J. AND AGURELL, S. (1968). Biosynthesis of mescaline and anhalamine in peyote. Tetrahedron Lett., pp. 4437-44.

MANN, P. J. G. AND QUASTEL, J. H. (1940). Benzedrine ( $\beta$-phenylisopropylamine) and brain metabolism. Biochem. J. 34, $414-431$.

OтA, J. (1948). Inhibition of amine oxidase by benzedrine derivatives. Bull. Chem. Soc. Jap. 21, $75-77$.

Peretz, D. I., Smythites, J. R. AND Gibson, W. C. (1955). A new hallucinogen: 3,4,5-trimethoxyphenyl- $\beta$-aminopropane. J. Ment. Sci. 101, 317-329.

RATCLIFFE, F. (1971). The effect of mescaline and bufotenine on some central actions of noradrenaline. Arch. Int. Pharmacodyn. 194, 147-157.

Shulgin, A. T. (1964). 3-Methoxy-4,5-methylenedioxyamphetamine, a new psychotomimetic agent. Nature (London) 201, 1120-1121.

Shulgin, A. T. (1970). Chemistry and structure-activity relationships of the psychotomimetics In: Psychotomimetic Drugs (D. H. Efron, ed.), pp. 21-41. Raven Press, New York.

Shulgin, A. T., Bunnell, S. And Sargent, T. (1961). The psychotomimetic properties of 3,4,5-trimethoxyamphetamine. Nature (London) 189, 1011-1012.

SkITA, A. AND KeIL, F. (1932). Reduction of nitrostyrenes to $\omega$-phenylethylamines. Chem. Ber. 65B, 424-431.

SMYTHIES, J. R. AND Levy, C. K. (1960). The comparative psychopharmacology of some mescaline analogs. J. Ment. Sci. 106, 531-536.

SMYTHIES, J. R. AND Sykes, E. A. (1966). Structure-activity relationship studies on mescaline: The effect of dimethoxyphenylethylamine and $\mathrm{N}: \mathrm{N}$-dimethyl mescaline on the conditioned avoidance response in the rat. Psychopharmacologie 8, 324-330.

SNYDER, S. H. AND RICHELSEON, E. (1968). Psychedelic drugs: steric factors predicting psychotropic activity. Proc. Nat. Acad. Sci. U.S. 60, 206-213.

SPECK, L. B. (1957). Toxicity and effects of increasing doses of mescaline. J. Pharmacol. Exp. Ther. 119, 78-84.

STOCKINGS, G. T.(1940). A clinical study of the mescaline psychosis, with special reference to the mechanism of the genesis of schizophrenic and other psychotic states. J. Ment. Sci. 86, $29-47$. 